\title{
WAJAH BARU GERAKAN DAKWAH KAMPUS (GERAKAN TARBIYAH) ERA SEKARANG
}

\author{
RIZKI NUR FADILAH, TILAS LESTARI, AZ-ZAFIRA SYAIRUL \\ FAIZAH, AHMAD FAUZAN HIDAYATULLAH \\ Departemen Pendidikan Matematika dan Kimia \\ Universitas Islam Negeri (UIN) Walisongo Semarang \\ Email : Rizki_1808056064@student.walisongo.ac.id, \\ tilaslestari_1808076038@student.walisongo.ac.id, \\ azzafira_1808076060@student.walisongo.ac.id, \\ afhidayatullah@walisongo.ac.id
}

\begin{abstract}
:
The campus propaganda movement began with a movement carried out by students of the Salman ITB Mosque spearheaded by Indonesian students studying in Egypt. These Egyptian alumni learned from the Ikhwanul Muslimin and they taught their knowlage and exsperiences in Indonesia country after they go home to Indonesia country. The Tarbiyah Movement which is currently transforming into the Justice Party then becomes the Social Justice Party (PKS). The change to PKS was a result of the opening of public space after the falling of President Soeharto. After being transformed into a political party, is this campus Da'wah Movement still following the ideology of the Ikhwanul Muslimin and to find out why the campus missionary movement is transforming into PKS. This is our reason to write this journal. The method used in this research is literature study, analytical descriptive, and comparative. The results of this study were produced from surgical journals and theses.
\end{abstract}

Keywords : Da'wah movements, Tarbiyah, PKS, Students, politics.

\section{PENDAHULUAN}

Gerakan Tarbiyah berawal dari gerakan dakwah yang dilakukan oleh mahasiswa yang sedang menyusun skripsi di Masjid Salman ITB. Awalnya aktivitas ini dilakukan oleh para alumnus Arab Saudi dan Mesir berupa salat Jumat, diskusi dan mengadakan forum-forum kecil. Tak hanya mahasiswa ITB yang melakukan Gerakan Tarbiyah, universitas lain juga melakukan hal demikian seperti UGM, UI, UNAIR, IPB dan lainnya. ${ }^{1}$

Gerakan Tarbiyah ini dipelopori oleh Ikhwanul Muslimin. Gerakan Ihwanul Muslimin adalah gerakan yang dipelopori oleh Hasan Al Banna, merupakan salah satu gerakan militan islam mesir. Pada awalnya Ikhwanul Muslimin melihat bahwa Saudi Arabia adalah negara islam dengan tingkat kriminal paling rendah. Karena Arab Saudi menjadikan islam satu-satunya sumber

${ }^{1}$ Miftauddin. 2009.Pengarah idiologi ikhwanul muslimin teradap partai keadilan sejatera $(P K S)$ di Indonesia. Hal.46 
perundang-undangan, seluruh pemerintahan berbasis islam, dan berpedoman pada Al Quran dan Hadist. Inilah yang melatarbelakangi Gerakan Ihwanul Muslimin untuk menerapkan hal tersebut di negara Mesir.

Di Indonesia terdapat gerakan tarbiyah yang semua ajaranya sesuai dengan Ihwanul Muslimin Mesir. Gerkan tarbiyah ini berasal dari mahasiswa Indonesia yang menempuh studi di Mesir, kemudian mereka pulang ke Indonesia mengaplikasikan pemahaman yang mereka dapat sewaktu mengikuti organisasi Ihwanul Muslimin di Mesir.

Di akhir tahun 1990-an kondisi sosial politik Indonesia mulai berubah secara drastis, gerakan-gerakan islam yang tadinya ditekan oleh aparat pemerintah agar tidak hidup, malah sebaliknya berkembang pesat. Puncak dari perubahan ini adalah terjadi pada tanggal 21 Mei 1998 dimana Presiden Soeharto mundur dari jabatannya. Setelah Soeharto lengser, kepemimpinan beralih ketangan BJ Habibie. Pada masa inilah era multi partai dimulai. Para mantan aktivis dakwah kampus generasi pertama dan juga alumni Timur Tengah yang selama ini aktif di dunia dakwah kampus pun mencoba memanfaatkan situasi tersebut.

Lahirnya gerakan dakwah kampus merupakan cikal bakal kemunculan kader-kader partai keadilan diera reformasi berawal dari munculnya kelompok anak muda yang memiliki semangat tinggi dalam mempelajari dan mengamalkan islam, sebagai respon dari tekanan politik yang dilakukan politik orde baru ketika itu terhadap umat islam. Dan juga adanya ruang publik yang relatif lapang.

Akhirnya lewat proses yang panjang, para penggiat dakwah ini pun mendeklarasikan sebuah partai politik yang diberi nama Partai Keadilan (PK) pada tanggal 9 Agustus 1998. Dalam partai ini tetap ada pemikiran Ikhwanul Muslimin dalam ide-ide politik. Dalam perjalanannya PK masuk dalam tujuh besar partai politik pemenang pemilu. Namun seiring berjalannya waktu PK mengubah nama menjadi Partai Keadilan Sejahtera (PKS). Perubahan nama tersebut dikarenakan hasil pemilu PK mendapatkan suara $<2 \%$, sehingga PK tidak diperbolehkan mengikuti pemilu dan membentuk partai baru dengan nama PKS.

\section{PEMBAHASAN}

\section{Hubungan PKS dan Ikhwanul Muslimin}

Sejarah lahirnya Partai Keadilan yang kemudian menjadi Partai Keadilan Sejahtera tak lepas dari kondisi riil sejarah umat Islam Indonesia dari Presiden Soekarno sampai Presiden Soeharto di era orde baru. Itu bisa dilihat dari diskriminasi yang dilakukan oleh para pemimpin negeri ini terhadap umat Islam.

Partai Keadilan adalah partai politik yang didirikan oleh sejumlah 
aktivis muslim Indonesia baik dari dalam negeri maupun luar negeri. Beberapa pendiri Partai Keadilan yang berasal dari kalangan kampus dalam negeri yang diantaranya berasal dari mantan aktivis Universitas Negeri ternama di Indonesia, seperti, UI, IPB, UNDIP, ITB dan UGM.

Lahirnya gerakan dakwah kampus yang merupakan cikal bakal kemunculan kader-kader Partai Keadilan di era reformasi berawal dari munculnya kelompok anak muda yang memiliki semangat tinggi dalam mempelajari dan mengamalkan Islam, sebagai respon dari tekanan politik yang dilakukan pemerintah orde baru ketika itu terhadap umat Islam, dan juga adanya ruang publik yang relatif lapang yang bernama masjid atau mushalla kampus. Tempat dimana idealisme kaum muda Islam itu mengalami persemaian ideal secara tepat. Sementara masjid kampus adalah basis yang dijadikan benteng pertahanan sekaligus basis gerakan. Faktor diatas membuat anak-anak muda bersemangat dalam perjuangan dakwah Islam yang semuanya bermula dari masjid Salman Institut Teknologi Bandung (ITB). Kelompok santri inilah yang pertama kali membuat kelompok-kelompok kecil bercirikan Islam. $^{2}$

Mereka terlembagakan dalam lingkungan usrah-usrah yang akrab dengan pemikiran Ikhwanul Muslimin. Orientasi ke-ikhwanul muslimin-an inilah yang menjadi pintu masuk bagi alumni Timur Tengah sebagai narasumber atau penterjemah gagasan-gagasan Islam Timur Tengah di Indonesia, mereka terlibat dalam kegiatan dakwah kampus. Kenyataan bahwa Timur Tengah merupakan wilayah yang memiliki keterikatan erat dengan Indonesia. Sesuatu yang tidak bisa dibantah dan ini lebih banyak dipengaruhi oleh faktor agama dan politik, di mana sejak lama Timur Tengah telah memberikan kontribusi pemikiran dan gerakan dalam dinamika keagamaan dan politik di Indonesia.

Pada era sebelum kemerdekaan bermunculan setelah pendirinya berinteraksi dengan pemikiran dan gerakan Islam di Arab Saudi maupun Mesir contohnya Muhammadiyah. PKS yang terinspirasi oleh gerakan Ikhwanul Muslimin di Mesir, gerakan tarbiyah yang merupakan tulang punggung dan pendukung utama partai ini mencoba untuk memformulakan ajaran ajaran Islam dengan kehidupan sehari-hari.

Sesuai dengan latar belakang pembinaan ideologis yang selama ini mereka dapat dan terapkan, maka ketika gerakan dakwah ini menggunakan partai politik sebagai payungnya. Meski demikian, ide-ide dan pemikiran

${ }^{2}$ Miftauddin. 2009.Pengarah idiologi ikhwanul muslimin teradap partai keadilan sejatera $(P K S)$ di Indonesia. Hal.47 
Ikhwanul Muslimin tetap melekat kental dalam tubuh gerakan dakwah ini. Partai Keadilan yang pada Pemilu 1999 mendapatkan 1,4 juta suara atau 1,36 $\%$ berhasil mendudukkan 7 orang wakilnya di Senayan. Partai Keadilan menempati 7 besar partai pemenang Pemilu. Karena terganjal Undangundang Pemilu mengenai Electoral Treshold (batas suara minimal harus $2 \%$ ) maka PK mengubah nama menjadi Partai Keadilan Sejahtera (PKS), setelah sebelumnya harus memenuhi persyaratan-persyaratan yang telah ditentukan Komisi Pemilihan Umum (KPU). Pendeklarasian Partai Keadilan Sejahtera ini dilakukan di lapangan Monas Jakarta pada hari Ahad tanggal 18 Shafar $1424 \mathrm{H}$ bertepatan dengan tanggal 20 April 2003.

Ide-ide pemikiran Ikhwanul Muslimin yang diterapkan oleh PKS yang mulai dari proses kemunculannya sampai sekarang adalah sebuah hal yang cukup menarik untuk diteliti. Karena ide dan gagasan Ikhwanul Muslimin merupakan dua metode gerakan perubahan, yaitu metode Jamaluddin Al Afghani dan metode Muhammad Abduh disertai studi pendalaman dan ketajaman intelektual serta bimbingan dari Allah SWT . Pengaruh Ikhwanul Muslimin yang telah melekat diaplikasikan dengan sangat baik sekali oleh para kader dan aktivis PKS.

Namun bayang-bayang Ikhwanul Muslimin dalam diri partai ini membuat banyak pengamat Islam dan politik menganggap PKS tidak ada bedanya dengan kelompok-kelompok fundamentalis saat ini, karena mengingat Ikhwanul Muslimin dalam persepsi mereka adalah organisasi fundamentalis terlarang di Mesir yang dianggap ancaman bagi kelangsungan pemerintah yang berkuasa apabila dilihat dari sisi politik ${ }^{3}$.

Partai Keadilan didirikan dengan sebuah keputusan yang diambil berdasarkan survei yang dilakukan kepada para aktivis gerakan dakwah di seluruh Indonesia bahkan luar negeri. Inti pertanyaan yang diajukan dalam jajak pendapat tersebut adalah bentuk apa yang ditampilkan untuk muncul ke tengah publik pada era reformasi, apakah bentuk organisasi massa atau organisasi politik, atau tetap mempertahankan penampilan yang selama ini digunakan yaitu dalam bentuk yayasan atau lembaga-lembaga dakwah. ${ }^{9}$

Bentuk transformasi GDK (Gerakan Dakwah Kampus) menjadi Partai Keadilan (PK) barangkali bentuk transformasi paling fenomenal yang dilakukan oleh gerakan dakwah ini. Dikatakan fenomenal karena beberapa alasan, di antaranya;

${ }^{3}$ Miftauddin. 2009.Pengarah idiologi ikhwanul muslimin teradap partai keadilan sejatera $(P K S)$ di Indonesia. Hal.48 
a. Pilihan mendirikan partai politik merupakan bentuk pemunculan publik yang paling utuh dari gerakan dakwah yang selama ini bergerak dengan banyak nama dan banyak kantong-kantongnya itu.

b. Pilihan untuk mendirikan partai politik itu adalah sebuah keputusan yang tidak pernah diduga sebelumnya bahkan oleh para kadernya sendiri dan memicu kontroversi

c. Pilihan tersebut membawa konsekuensi pada masuknya gerakan dakwah ke dalam politik praktis dengan logika dan sistemnya sendiri yang di masa lalu merupakan sesuatu yang sempat mereka jauhi. Artinya selama ini trade omark mereka adalah aktivitas dakwah sedangkan berpolitik selama ini hampir-hampir mereka tidak pernah sentuh.

\section{Alasan Gerakan Dakwah Kampus Bertransformasi Menjadi PKS}

Pada tahun 1980-an, Gerakan dakwah kampus telah tersebar di seluruh universitas di Indonesia. Gerakan dakwah ini dapat dikatakan di pelopori oleh pendiri Dewan Dakwah Islamiyah Indonesia (DDII) yaitu Muhammad Natsir. Peran DDII yang paling penting adalah sebagai pelopor dari lembaga Mujahid Dakwah yang dipimpin oleh Imaddudin Ibrahim yang aktif dan berkontribusi dalam pelatihan-pelatihan keagamaan seperti pengajian di masjid Salman yang terletak di ITB.

Pada tahun 1985, saat pemerintahan orde baru yang dimpin oleh Soeharto mewajibkan seluruh organisasi masa untuk menggunakan pancasila sebagai asasnya. Hal ini yang mendorong gerakan dakwah kampus mau tidak mau harus mengikuti aturan tersebut sehingga mereka memilih untuk bertransformasi menjadi partai politik yang diberi nama partai keadilan yang seiring berjalannya waktu dan alasan tertentu berubah nama lagi menjadi Partai Keadilan Sejahtera (PKS).

Berubahnya gerakan dakwah kampus menjadi partai politik juga didukung dengan kemenangan jamaah tarbiyah dikalangan mahasiswa kader-kader rohis dan aktivis dakwah dikampus-kampus. Seorang kader jamaah Tarbiyah yang bernama Mustafa Kamal menang dalam pemilihan mahasiswa untuk Fakultas Ilmu Pengetahuan Budaya Universitas Indonesia pada tahun 1993. Mustafa Kamal ini tercatat sebagai kader jamaah tarbiyah pertama yang memegang kekuasaan di level universitas. Tahun berikutnya, kader dari jamaah tarbiyah yang lain menang lagi dalam pemilihan ketua senat di universitas yang sama yaitu Universitas Indonesia, kader ini bernama Zulkiflimansyah.

Jamaah tarbiyah juga mendirikan unit-unit kegiatan mahasiswa secara resmi didalam kampus-kampus yang disebut lembaga dakwah kampus (LDK). Sebutan antara jamaah tarbiyah yang satu dengan yang lain dikenal sebagai usrah 
yang artinya keluarga. Kegiatan dari LDK ini salah satunya yaitu dengan mendirikan kelompok-kelompok kecil pengajian yang bertempat di masjid kampus. Dalam kelompok-kelompok kecil inilah LDK merekrut kader-kadernya. Cara ini sama dengan sistem perekrutan dari Ikhwanul Muslimin. Hal ini wajar dan mudah sekali terjadi karena Gerakan Tarbiyah sendiri merupakan anak cabang Ikhwanul Muslimin yang pusatnya di Mesir dan mendirikan cabang di Indonesia dengan nama Gerakan Tarbiyah. Selain dengan pengajian yang diikuti oleh kelompok kecil, kegiatan dari LDK dapat dibuktikan dengan banyaknya mahasiswi yang memakai hijab di kampus.

Melalui struktur organisasi semacam ini, aktivitas dakwah-dakwah kampus terus berkembang pesat dengan jumlah jamaah yang semakin banyak hingga saat ini. Dengan jumlah massa yang banyak tentu akan menguntungkan jika gerakan dakwah kampus ini bertransformasi menjadi partai politik, pasti akan memiliki massa pendukung yang banyak dari jamaah.

Pada tahun 1986, LDK sepakat untuk membentuk FSDLK (Forum Silaturahmi Lembaga Dakwah Kampus). FSLDK sering mengadakan pertemuanpertemuan di setiap tahunnya. Seiring berjalannya waktu, yakni pada pertemuan FSLDK kesepuluh di kota Malang dimanfaatkan oleh Kesatuan Aksi Mahasiswa Muslim Indonesia (KAMMI) untuk mendeklarasikan pertimbangan-pertimbangan pendirian sebuah partai islam setelah mundurnya Soeharto. KAMMI adalah oraganisasi yang dipimpin oleh Fahri Hamzah sebagai salah satu organisasi yang paling bersemangat untuk menyuarakan tuntutan reformasi kepada pemerintahan Soeharto.

Kita tahu sendiri bagaimana pemerintahan orde baru yang dipimpin oleh Soeharto selama kurang lebih 32 tahun dengan segala penyimpanganpenyimpangan dan ketidakadilan yang terjadi, seperti Praktek KKN yang merajalela, pelanggaran HAM, pembangunan tidak merata, penyimpangan pancasila,dan lain sebagainya. Penyimpangan-penyimpangan ini sangat tidak sesuai dengan ajaran-ajaran agama Islam. Dengan penyimpangan-penyimpangan ini semakin menguatkan keinginan dan meningkatkan semangat kader-kader dari jamaah tarbiyah untuk ikut serta dalam pemerintahan. Dengan harapan dapat mengubah pemerintahan menjadi lebih tertata dan tidak terjadi penyimpangan yang merugikan banyak pihak terutama rakyat.

Untuk ikut serta dalam menata pemerintahan menjadi lebih baik, kaderkader jamaah dari Tarbiyah ini berkeinginan berubah menjadi partai politik yang nantinya diharapkan kader-kader jamaah tarbiyah yang telah berpengalamam dalam memimpin gerakan-gerakan kampus dapat menjadi pemimpin yang mampu membawa Indonesia menjadi lebih sejahtera. 
Partai politik Islam yang diusulkan oleh KAMMI diberi nama Partai Keadilan. Deklarasi Partai Keadilan dilakukan pada 20 juli 1998 di masjid AlAzhar, Kebayoran Baru Jakarta dengan presiden pertamanya yaitu Nurmahmudi Ismail. Dalam keikutsertaannya sebagai Parpol, PK gagal untuk memenuhi ambang batas parlemen sebesar 2\% sehingga terpaksa harus bergabung dengan partai islam lainnya pada bulan Mei 1999. Kegagalan PK utntuk memenuhi ambang batas tersebut mengharuskan PK berganti nama sesuai dengan peraturan pemerintah. Akhirnya pada tanggal 3 Juli 2003 PK resmi berubah nama menjadi PKS, setelah menyelesaikan seluruh proses verikasi. Kelahiran PKS erat kaitannya dengan gerakan Islam berbasis masa kampus dan cendekiawan yang muncul sebagai tanggapan atas tekanan politik pemerintah Orde Baru terhadap umat Islam.

\section{Prinsi Kebijakan PKS dan Bentuk Rekruitmen anggota PKS}

Prinsip Kebijakan PKS Prinsip kebijakan PKS8 sebagaimana ketetapan Majelis Syuro tentang Kebijakan Dasar PKS adalah:

1) Al-Syumuliyah (Lengkap dan Integral) Sesuai dengan dakwah Islam yang syamil, maka setiap kebijakan partai akan selalu dirumuskan dengan mempertimbangkan berbagai aspek, memandangnya dari berbagai perspektif serta mensinkronkan antara satu aspek dengan aspek lain.

2) Al-Islah (Reformatif) Setiap kebijakan, program dan langkah yang ditempuh partai selalu berorientasi pada perbaikan (ishlah), baik yang berkaitan dengan perbaikan individu, masyarakat ataupun yang berkaitan dengan pemerintahan dan negara, dalam rangka meninggikan kalimat Allah SWT, memenangkan syari'ah-Nya dan menegakkan daulah-Nya.

3) Al-Syari'ah (Konstitusional) Syari'ah yang berisi hukum-hukum Allah SWT telah menetapkan hubungan pokok antara manusia (hablun min Allah) dan hubungan terhadap diri sendiri dan orang lain (hablun min al-naas). Menjunjung tinggi syari'ah, ketundukkan dan komitmen kepadanya dalam seluruh aspek kehidupan merupakan kewajiban setiap Muslim sebagai konsekuensi keimanannya.

4) Al-Wasathiyah (Moderat) Masyarakat Muslim disebut sebagai masyarakat "tengah" (ummatan wasathah). Simbol moralitas masyarakat Islam tersebut melahirkan prilaku, sikap, dan watak moderat (washathiyah) dalam sikap dan interaksi Muslim dalam berbagai persoalan. Al-Wasathyah yang telah menjadi ciri Islam baik dalam aspek-aspek nazhariyah (teoritis), dan amaliyah (operasional) atau aspek tarbiyah (pendidikan) dan tasyri'iyah (perundangundangan) harus merefleksi pada aspek ideologi ataupun tashawwur 
(persepsi), ibadah, yang bersifat ritual, akhlak, adab, tasyri' dan dalam semua kebijakan, program dan prilaku politik PKS. Dalam tataran praktis sikap kemoderatan ini dinyatakan bila dalam penolakannya terhadap segala bentuk ekstrimis dan eksagritas kezhaliman dan kebathilan.

5) Al-Istiqamah (Komit dan konsisten) Oleh sebab berpegang teguh kepada ajaran dan aturan Islam (QS 43:23) merupakan ciri seorang Muslim, maka komitmen dan konsistensi kepada gerakan Islam harus menjadi inspirasi setiap gerakannya. Konsekuensinya seluruh kebijakan, program dan langkah partai harus istqamah (taat asas) pada "hukum transenden" yang ditemukan dalam Al-Qur'an dan As-Sunnah.

6) Al-Numuw wa al-Tathawwur (Tumbuh dan berkembang) Konsistensi yang menjadi watak PKS tidak boleh melahirkan stagnan bagi gerakan dan kehilangan kreativitasnya yang orisinal. Maka prinsip Al-Numuw wa alTathawwur (pertumbuhan yang bersifat vertikal dan berkembang yang bersifat horizontal) harus menjadi prinsip gerakannya dengan tetap mengacu kepada kaidah yang bersumber dari nilai-nilai Islam.

7) Al-Tadarruj wa al-Tawazun (Bertahan, seimbang dan proporsional) Pertumbuhan dan perkembangan gerakan dakwah partai harus dilalui secara bertahap dan proporsional, sesuai dengan Sunatullah yang berlaku di jagat raya ini. Seluruh sistem Islam berdiri di atas landasan kebertahapan dan keseimbangan. Kebertahapan dan keseimbangan merupakan tata alamiah yang tidak akan mengalami perubahan.

8) Al-Awlawiyat wa al-Mashlahah (Skala prioritas dan prioritas kemanfaatan) Prinsip Al-Awlawiyat dalam gerakan pada hakekatnya refleksi dari budaya berpikir strategis. Oleh sebab itu, kebijakan, program dan langkah-langkah operasionalnya didasarkan pada visi dan misi partai. PKS yakin bahwa sebaikbaiknya Muslim adalah yang paling bermanfaat bagi kepentingan manusia.

9) Al-Hulul (Solusi) PKS sesuai dengan namanya, ia memperjuangkan aspekaspek yang tidak hanya berhenti pada janji, teori maupun kegiatan yang tidak dirasakan manfaatnya oleh umat. Partai dan aktivisnya harus mengarahkan aktivitas dan program partai politik untuk menjadi solusi dan merealisasikannya di setiap aktivitas yang mereka tempuh.

10) Al-Mustaqbaliyah (Orientasi masa depan) Pada kenyataannya, tiga dimensi waktu (masa lalu, masa kini, dan masa mendatang) merupakan realitas yang saling berhubungan. Disadari, sasaran dakwah yang akan diwujudkan merupakan sasaran besar, yaitu tegaknya agama Allah SWT di bumi yang menyebarluaskan keadilan dan kesejahteraan bagi seluruh umat manusia, yang bisa jadi yang akan menikmati keberhasilannya adalah generasi mendatang. 
Maka seyogyanya setiap kebijakan yang diambil dan program-program yang dicanangkan mengaitkan ketiga dimensi waktu tersebut.

11) Al-'Alamiyah (Bagian dari dakwah dunia) Pada hakikatnya dakwah islamiyah, baik tujuan maupun sasaran yang akan dicapai itu bersifat 'alamiyah (mendunia) sejalan dengan universalitas Islam. Hal ini telah menjadi sunnatuddakwah. Ia merupakan aktivitas yang tidak kenal batas etnisitas, negara atau daerah tertentu. Kenyataan itu menegaskan bahwa eksistensi dakwah kita merupakan bagian dari dakwah alamiah.

\section{SIMPULAN}

Lahirnya gerakan dakwah kampus yang merupakan cikal bakal kemunculan kader-kader Partai Keadilan di era reformasi. Berubahnya gerakan dakwah kampus menjadi partai politik juga didukung dengan kemenangan jamaah tarbiyah dikalangan mahasiswa, kader-kader rohis dan aktivis dakwah dikampuskampus. Pengaruh Ikhwanul Muslimin yang telah melekat diaplikasikan dengan sangat baik sekali oleh para kader dan aktivis PKS.

\section{DAFTAR PUSTAKA}

Al Ghazali, Abdul Hamid, Meretas Jalan Kebangkitan Islam; Peta Pemikiran Hasan Al Banna, terj, Solo; Era Intermedia 2001

Al Khatib, M. Abdullah dan Hamid, M. Abdul Halim, Konsep Pemikiran Gerakan Ikhwan; Kajian Analitik terhadap Risalah Ta'alim, terj, Bandung; Asy Syamil, 2001

Al Qardhawi, Yusuf, 70 Tahun al Ikhwan al Muslimun; Kilas Balik Dakwah Tarbiyah dan Jihad, terj, Jakarta: Pustaka Al Kautsar, 1999

Mahmudi ,Yon. 2008. Islamising Indonesia: The Rise of Jemaah tarbiyah and prosperous justicy party (PKS). Canberra : Australian National University Press.

Miftahuddin. 2009. Pengaruh Idiologi Ikhwanul Muslimin terhadap PartaiKeadilan Sosial (PKS) di Indonesia. Skripsi. Tidak diterbitkan. Fakultas dan Filsafat. Universitas Islam Negeri Syarif Hidayatullah:Jakarta.

Jullian Ekky. 2018. Pengawasan Partai Politik Terhadap Kader di Legislatif (Studi Kasus di DPW Partai Keadilan Sejahtera Provinsi Lampung).Skripsi. Tidak diterbitkan. Fakultas Ilmu Sosial dan Ilmu Politik. Universitas Bandar Lampung:Lampung. 